\title{
The potential role of background ozone on current and emerging air issues: An overview
}

\author{
N. Reid·D. Yap · R. Bloxam
}

Received: 20 November 2007 / Accepted: 4 April 2008/Published online: 22 May 2008

(C) Springer Science + Business Media B.V. 2008

\begin{abstract}
It is now widely recognized that background ozone may form a significant part of the concentration and, thus, of the health and ecosystem impacts, experienced at many locations. This can be extremely important, as the background concentration is the level below which concentrations cannot be reduced by local efforts alone. In discussing background ozone, it is important to be clear what is meant by the term. Slightly different interpretations of the exact understanding of what constitutes background widen the uncertainty in reported values. Nevertheless, the central tendency to reported background ozone concentrations may be estimated as 25 to $40 \mathrm{ppb}$ for measurements made worldwide. The large majority of recently reported work indicates that these background concentrations are increasing at a rate ranging up to about 0.3 to $0.5 \mathrm{ppb}$ per year. Ozone lifted to levels above the boundary layer can be transported very long (intercontinental) distances. As a result, Asia, North America, and Europe can all contribute to each other's background ozone concentrations. In this context, the rapid industrial growth in Asia and the expected accompanying increased precursor emissions, could prove to be significant.
\end{abstract}

Keywords Background · Ozone · Troposphere · Health · Climate change

\footnotetext{
N. Reid $(\triangle)$

Smeraldo Environmental,

46 Four Oaks Gate,

Toronto M4J 2X2, Canada

e-mail: nwreid@sympatico.ca

D. Yap $\cdot$ R. Bloxam

Ontario Ministry of the Environment,

125 Resources Road,

Toronto M9P 3V6, Canada
}

\section{Introduction}

Ozone $\left(\mathrm{O}_{3}\right)$ is found at all levels in the atmosphere. In the stratosphere, it plays an extremely important and beneficial role in screening the lower layers of the atmosphere and the surface of the earth from the sun's harmful ultraviolet radiation. In the troposphere, and especially at the surface of the earth, ozone has been shown to be harmful to human health, vegetation, and certain materials. Ozone in the troposphere is also a significant greenhouse gas. This review concentrates on ozone in the lower atmosphere, specifically in the planetary boundary layer, which is the well-mixed layer closest to the earth's surface. The depth of this layer typically ranges up to 1 to $2 \mathrm{~km}$, and the depth has an important bearing on pollutant concentrations, as it determines the volume into which pollutants are mixed. In specific cases, if necessary to avoid confusion, ozone will be described as tropospheric or stratospheric but, without this designation, tropospheric ozone is to be understood.

Ozone is not emitted directly to the atmosphere, but is formed in reactions between oxides of nitrogen $\left(\mathrm{NO}_{x}\right.$, which is the sum of $\mathrm{NO}$, nitric oxide, and $\mathrm{NO}_{2}$, nitrogen dioxide) and volatile organic compounds (VOC), these reactions being driven by absorbed solar radiation (Seinfeld and Pandis 1998; Finlayson-Pitts and Pitts 1999). Significant anthropogenic emissions of oxides of nitrogen occur in association with combustion processes, e.g., from motor vehicles, thermal power generation, and industrial and other boilers. Volatile organic compound emissions occur wherever there is incomplete combustion, e.g., from motor vehicles, and also in the manufacture, processing, and use of such compounds, e.g., in the petrochemical industry, motor fuel production and distribution, and solvent use.

There are also natural sources of $\mathrm{NO}_{x}$, such as production by lightning and direct emission from soils, 
and of VOC, mainly by emission from vegetation. In the context of ozone production, carbon monoxide, $\mathrm{CO}$, is included as a VOC. It has a relatively low reactivity to ozone formation, but this is compensated for by its high abundance, relative to other VOC. Methane, $\mathrm{CH}_{4}$, also has relatively low reactivity but high abundance. Methane and $\mathrm{CO}$ contribute to ozone production in the polluted atmosphere, but are of particular importance in the photochemical production of ozone in the free troposphere.

Measures for the reduction of ozone involve reducing the emissions of both $\mathrm{NO}_{x}$ and $\mathrm{VOC}$ to the atmosphere. The situation is complicated by the highly nonlinear nature of the atmospheric reactions which lead to the formation of ozone. In other words, a reduction of $X \%$ in emissions does not necessarily produce an $X \%$ reduction in ozone concentrations. Indeed, it is not at all uncommon, notably in highly urbanized areas, for a reduction in $\mathrm{NO}_{x}$ emissions to lead to a local increase in ozone concentrations because of reduced scavenging by NO. However, increases in $\mathrm{NO}_{x}$ emissions will generally result in increased ozone concentrations at downwind locations.

A further complication in the design of ozone control measures is the presence of a significant concentration of background ozone. Precursor emissions in the region of concern lead to production of additional ozone, which is approximately additive to the background. However, it is only the local emissions which are controllable by any jurisdiction, meaning that the background concentration is the lowest level that can be achieved.

Policy discussions in several jurisdictions refer to controllable ozone. As discussed above, this is the component of the locally occurring ozone which can be controlled by controlling emissions within the jurisdiction. The US EPA uses the term Policy Relevant Background ozone (OAQPS 2007), which is the ozone concentration which would be observed in the absence of emissions of anthropogenic precursors in the US, Canada, or Mexico. Specifically, Policy Relevant Background ozone includes ozone from natural precursor emissions in the US, Canada, and Mexico, and ozone arising from the transport of ozone or its precursors, emitted from both natural and anthropogenic sources, from outside the US, Canada, and Mexico.

\section{Background ozone}

Sources

In any region, measurable, sometimes significant, concentrations of ozone will be found, even in the total absence of local emissions. This background concentration of ozone will generally have both a natural and an anthropogenic component.
The natural component results from the reaction of naturally emitted $\mathrm{NO}_{x}$ and VOC. Nitrogen oxides are naturally emitted from soils, as a consequence of microbial processes occurring in the soil, and may also be produced by lightning and by forest fires (many of which are started by lightning strikes). The predominant source for biogenic (natural) VOC is vegetation. Vegetatively emitted VOC, mainly pinenes and terpenes, are highly reactive in the formation of ozone, and the magnitude of their emissions increases with increased sunlight and temperature, just the conditions which favor ozone production. Additional natural sources of VOC, mainly methane, are emissions from wetlands and geological and geothermal leakage from underground deposits.

Possible natural sources of ozone itself include production by lightning and injection of ozone-rich air from the stratosphere. Although the stratosphere and the troposphere are generally decoupled, with little transfer across the tropopause (the boundary between the two), conditions do arise in which such transfer can occur. For example, this phenomenon may be the result of a fold in the tropopause, leading to the formation of a "bubble" of stratospheric air, rich in ozone, which becomes trapped in the troposphere. Hocking et al. (2007) have recently reported that such stratospheric intrusions can be relatively frequent. Though the enhanced concentrations usually remain in the upper troposphere, their occasional contributions to high ozone concentrations at ground level are well documented.

Ozone in layers of the troposphere above the boundary layer can have a lifetime of many days or even a week or two. This is because the major loss processes, scavenging by nitric oxide and dry deposition, occur at or very close to the surface of the earth. This means that ozone produced in one region can, if lifted to higher levels, travel to another region, contributing there to the uncontrollable background for that region. Lifting mechanisms include deep convection in the atmosphere and orographic lifting (i.e., lifting of air parcels as the land surface rises to higher altitudes). It has been shown (Fiore et al. 2002; Jaffe et al. 2003; Liang et al. 2007) that western North America receives a background ozone contribution from Asia and Europe, while Auvray and Bey (2005) have demonstrated that Europe receives ozone transported from both North America and Asia.

\section{Determination of background}

Background ozone in a region may be determined by making measurements that are not impacted by emissions from the region itself. This will require that measurements be made in remote locations, usually at or near the region's boundary. In addition, appropriate protocols will be required to ensure that the measurements used to determine 
the background do not include any influence from the region of interest. Typically, this would involve considering measurements made when the wind is blowing only from the appropriate sector or preferably by ensuring that the back trajectories associated with the measurement times lie only within the appropriate sector, thus avoiding cases where the trajectory starts out over the study region, then turns enough that it reaches the measurement site from the clean sector (Carslaw 2005; Nolle et al. 2001; Simmonds et al. 2004).

Additional confirmation may be obtained by making simultaneous measurements of atmospheric components which may be indicative of anthropogenic pollution. Examples of such species include PAN, organic nitrates, $\mathrm{CO}, \mathrm{NO}_{x}$, and halogenated organic compounds (e.g., Altshuller and Lefohn 1996; Lefohn et al. 2001; Oltmans et al. 2006; Simmonds et al. 2004; Scheel et al. 1997; Bronnimann et al. 2000; Munger et al. 2002).

In an alternative approach, Fiore et al. $(2002,2003)$ have used a three-dimensional global tropospheric model with chemistry (GEOS-CHEM) in two ways to investigate background ozone in North America. The first method followed tagged tracers to separate ozone produced within North America from that produced outside the region. The tracer is a notional chemical species, which is subject to the same chemical and physical loss rates as ozone, but which originates from a specific geographic area. Ozone concentrations within the study domain were then deconstructed, according to the relative concentrations of tracer originating outside and inside the domain.

In the second approach, emission scenarios were modeled involving setting all anthropogenic emissions to zero globally (Scenario 1), within North America (Scenario 2) and outside North America (Scenario 3). Scenario 1 provides an estimate of the natural contribution to background ozone in North America, while Scenario 2 was used to estimate the contribution of anthropogenic emissions outside North America to the background. Scenario 3 allows estimation of the same contribution in a different way and was included, as comparing the two estimates provides a measure of the impact of nonlinearity in the formation and removal of ozone. The impact of nonlinearity was found to be small.

\section{Reported values of background}

Background ozone concentrations found in the course of this literature review are summarized in Table 1 . These concentrations were determined at many locations, almost all in the northern hemisphere, covering a wide range of topography and using a variety of methods to isolate background concentrations. Not surprisingly, therefore, a relatively wide range of background concentrations is listed in the table.
Background ozone levels have previously been reviewed by Vingarzan (2004). The data reported in this review were collected at sites characterized as "background", and ranges of annual median and annual maximum concentrations were reported. Many of the median concentrations were in the approximate range of 20 to $40 \mathrm{ppb}$, while the maxima ranged up to $116 \mathrm{ppb}$, with many of the stations reporting maximum ozone concentrations exceeding $100 \mathrm{ppb}$. These observations strongly suggest that the measurement sites listed in this review are not free of local or regional scale anthropogenic influence, as is confirmed by consideration of the site locations. For example, the Egbert, Ontario site is less than $100 \mathrm{~km}$ from Toronto, while Kejimkujik, in Nova Scotia, is impinged at times by polluted air parcels traveling up the east coast from Boston and other heavily urbanized areas further south.

Further determinations of background ozone have been reported subsequent to the review by Vingarzan (2004). For example, a summary of background ozone concentrations was provided by Fiore et al. (2003). The results of five research groups were quoted, values ranging overall between 25 and $45 \mathrm{ppb}$.

McKendry (2006) reported background ozone concentrations for British Columbia, building on the strong base provided by the review by Vingarzan (2004). He found that the background concentration was in the range 20-35 ppb, with the maximum occurring in the spring. Little evidence was found for a stratospheric contribution, but trans-Pacific transport was found to contribute as much as 5 to $15 \mathrm{ppb}$.

It may be noted that background concentrations reported for North America are similar to those found in Europe. This is particularly true if concentrations determined at high elevation are treated as a separate group, as ozone concentrations tend to increase with altitude. For example, Jaffe et al. (2003) have reported background concentrations ranging from 32 to $44 \mathrm{ppb}$ for six coastal California sites, while Altshuller and Lefohn (1996) suggested that background ozone concentrations in the US were $35 \pm 10 \mathrm{ppb}$. In comparison, Simmonds et al. (2004) in a careful analysis of measurements made at Mace Head, on the west coast of Ireland, determined that an appropriate range for the background ozone concentration was $39.3 \pm 6 \mathrm{ppb}$.

Other European results have been reported by Lindskog and Kindbom (2001) and Scheel et al. (1997), and have also been reviewed and summarized by ACCENT (2006; ACCENT is the Atmospheric Composition Change Network of Excellence funded by the European Community.). These studies found background ozone concentrations in the range 25 to $40 \mathrm{ppb}$.

Analysis of measurements made at an elevated site in Japan (Pochanart et al. 2004) indicated that the background ozone concentration was $44.4 \pm 3.6 \mathrm{ppb}$. Of this background, approximately $10 \mathrm{ppb}$ came from east Asia. 
Table 1 Background ozone concentrations at several locations

\begin{tabular}{|c|c|c|c|}
\hline Location & Concentration (ppb) & Reference & Comments \\
\hline \multicolumn{4}{|c|}{ Mainly North America: low elevation } \\
\hline US & Mainly 25 to 35 ; some higher & Fiore et al. (2002) & Determined from modeling using GEOS-CHEM \\
\hline US & Mainly 15 to 35 ; some to 45 & Fiore et al. (2003) & Determined from modeling using GEOS-CHEM \\
\hline US & $35 \pm 10$ & Altshuller and Lefohn (1996) & \\
\hline US, Europe & $50-60$ & Lefohn et al. (2001) & Stratospheric input \\
\hline $\begin{array}{l}\text { US, Canada, plus some } \\
\text { European }\end{array}$ & 28 to 50 & Lefohn et al. (2001) & Measurements at "clean" sites \\
\hline California & 32 to 44 & Jaffe et al. (2003) & Six coastal sites \\
\hline \multicolumn{4}{|l|}{ Europe: high elevation } \\
\hline Switzerland & 33 to 50 & Bronnimann et al. (2000) & $\begin{array}{l}\text { Concentration increased with altitude; highest on } \\
\text { Jungfraujoch }(3500 \mathrm{~m})\end{array}$ \\
\hline Mt. Cimone, Italy & $55 \pm 7$ & Bonasoni et al. (2000) & High elevation $(2165 \mathrm{~m})$ \\
\hline Germany, Switzerland & 30 to 60 & Naja et al. (2003) & High altitude locations. Back trajectory analysis \\
\hline \multicolumn{4}{|l|}{ Europe: low elevation } \\
\hline Mace Head, Ireland & $39.3 \pm 6.0$ & Simmonds et al. (2004) & Coastal site \\
\hline Europe & 30 & Auvray and Bey (2005) & Determined from modeling using GEOS-CHEM \\
\hline Europe & 30 to 35 & ACCENT 2006 & Review \\
\hline Gozo, Malta & 52.2 & Nolle et al. (2001) & Backround for Malta, but not for Europe \\
\hline Scandinavia & 25 to 40 & Lindskog and Kindbom (2001) & $\begin{array}{l}\text { Measurements made at remote sites in } \mathrm{N} \text {. } \\
\text { Scandinavia }\end{array}$ \\
\hline Europe & 30 to 37 & Scheel et al. (1997) & From analysis of measurements at several locations \\
\hline \multicolumn{4}{|c|}{ Eastern and oceanic: high elevation } \\
\hline Hawaii & "Substantial" (e.g., 60) & Cooper et al. (2005) & Stratospheric input \\
\hline Happo, Japan & $44.4 \pm 3.6$ & Pochanart et al. (2004) & Mountain site $(1840 \mathrm{~m})$ \\
\hline \multicolumn{4}{|c|}{ Multiple locations and reviews } \\
\hline Several sites globally & 25 to 50 & Oltmans et al. (2006) & Measurements at remote sites \\
\hline Review & 40 to 80 & Lefohn (2001) & \\
\hline Review & 14 to 47 & Vingarzan (2004) & Review of published values \\
\hline Review, US locations & 25 to 45 & Fiore et al. (2003) & \\
\hline
\end{tabular}

It may be suggested that there is a central tendency to the values given in Table 1 of approximately 25 to $40 \mathrm{ppb}$ for the sites at lower elevation. However, a discrepancy remains between the values reported recently by Lefohn and coworkers (e.g., Cooper et al. 2005; Lefohn et al. 2001), which are significantly higher than those determined using the GEOS-CHEM model (Fiore et al. 2003).

In their recent publications, Lefohn et al. (2001) and Cooper et al. (2005) maintain that significant inputs occur of air of stratospheric origin, bringing with it ozone concentrations of $60 \mathrm{ppb}$ or higher. On the other hand, research done using a modeling approach with the GEOSCHEM model supports background ozone concentrations that are much lower, often in the range 25 to $35 \mathrm{ppb}$.

This large discrepancy has significant implications for policy development, because if the background concentration is indeed as high as $60 \mathrm{ppb}$, even if only occasionally, extremely stringent controls could be required to achieve a design value which would satisfy the standard of $80 \mathrm{ppb}$, the current US value, let alone $75 \mathrm{ppb}$ the new standard. On the other hand, the results of Fiore et al., suggest that the background concentration is actually depressed under con- ditions which give rise to ozone episodes. In other words, the controllable portion of the ozone is higher than previously believed, and therefore more amenable to reduction.

It must be accepted that both methods, i.e., analysis of measurements and analysis using a model, are subject to some uncertainty. For example, direct analysis of measurements relies on the exclusion of contributions from regionally polluted air masses, while the modeling approach of Fiore et al. relies on the accuracy of the model and its predictions. Further work to resolve the differences is required.

Trends in background ozone

Measurements of ozone at ground level have been made since the $1850 \mathrm{~s}$, at which time it may be assumed that essentially all of the ozone was background. It is difficult to establish the accuracy of the early measurements, particularly because of their susceptibility to interference from other atmospheric constituents. However, a considerable effort was made by Marenco et al. (1994) to form a dataset that was as consistent as possible, for comparison with modern measurements. This work was subsequently ex- 
tended by Gros (2006), and the resultant temporal pattern is shown in Fig. 1.

As is shown in the figure, modern levels of ozone are approximately five times those reported in the mid-19th century. Even if the early measurements are in error by a factor of two or three, this still indicates a significant trend. It must be remembered that the measurements shown in Fig. 1 are for high altitude locations, which means that the absolute values are higher than the concentrations that will be found closer to sea level. Nevertheless, the entire data set is consistent with respect to the altitude of the measurement sites; in particular, the earliest (lowest concentration) and the latest (highest concentration) measurements were made at the same location, namely, Pic du Midi in France.

In her review of background ozone, Vingarzan (2004) also reported trends for a number of locations worldwide. Data for 22 of 30 stations showed increasing trends ranging from near 0 to $2.6 \%$ per year, with the majority of the annual increases being about 0.2 to $0.5 \%$ per year. Those sites at which ozone has decreased, reported rates in the range from close to 0 to $1.4 \%$ per year. It should be noted that while the sites for which results are reported are characterized as "background", it is not always clear that the measurements relate strictly to background ozone. For example, the largest rate of decrease ( $1.4 \%$ per year) was reported for Edmonton, Alberta. Given the magnitude of precursor emissions over much of the province of Alberta, it would require very careful analysis to isolate the effect of purely background ozone at this site.

Trend rates for a number of other monitoring locations have been retrieved from the current literature, and are reported in Table 2. Lindskog and Kindbom (2001) found little significant change for ozone concentrations measured at remote locations in northern Scandinavia. However, Naja et al. (2003) report that background ozone concentrations have increased by 5 to $10 \mathrm{ppb}$ over the 30 year period from 1970 to 1999 , corresponding to an annual rate of increase of approximately 0.15 to $0.3 \mathrm{ppb}$.

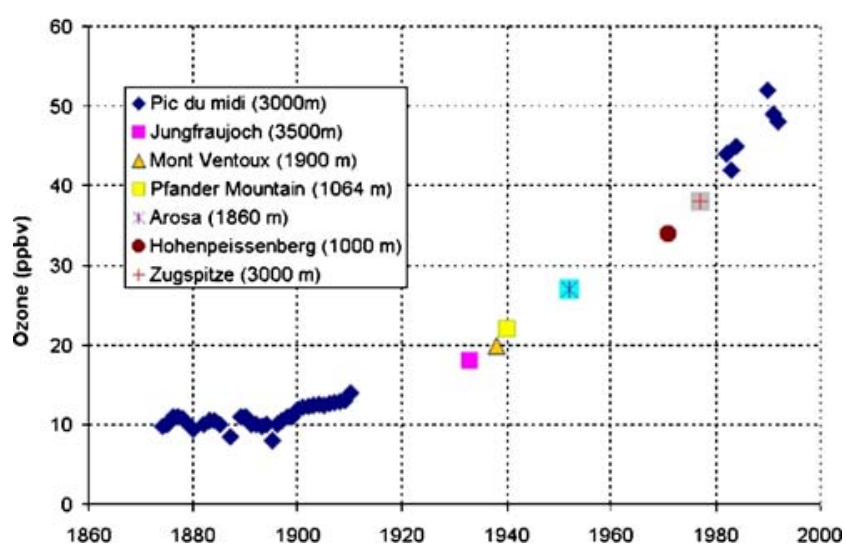

Fig. 1 Tropospheric ozone trends (Gros 2006, adapted from Marenco et al. 1994)
Results for high altitudes (above 3,000 $\mathrm{m}$ in Switzerland) presented by Bronnimann et al. (2000) indicate an overall increase of 0.8 to $1.3 \mathrm{ppb}$ over 9 to 11 years. This corresponds to approximately $0.1 \mathrm{ppb}$ per year.

Analysis of measurements made close to sea level show an increase of $1 \mathrm{ppb}$ over 4 years for Gozo, Malta, though these measurements probably include the influence of the industrialized and urbanized areas of the Mediterranean basin. At Mace Head, on the west coast of Ireland, Simmonds et al. (2004) found an annual rate of increase in background ozone of $0.49 \mathrm{ppb}$ per year. However, this value is higher than the value reported by Carslaw (2005) for the same location of $0.18 \mathrm{ppb}$.

Trends in background ozone for North American locations are found in the work of Jaffe at al. (2003), who reported an annual average increase of $0.5 \mathrm{ppb}$. The measurements from which this trend was derived were made in California. Lin et al. (2000) found a statistically significant rate of increase of background ozone over 20 years of 3 to $5 \mathrm{ppb}$ for the Spring and Fall. The greatest rate of increase was in the northeastern US.

Although the review by Vingarzan (2004) identified some decreasing trends in background ozone, none of the additional literature found in the present review has reported a decreasing trend in background ozone. Apart from one report of no significant increase, only increasing rates were found. The rate of increase ranged from approximately zero to $0.5 \mathrm{ppb}$ per year. If the background ozone concentration is approximately $35 \mathrm{ppb}$, this corresponds to a rate of up to $1.4 \%$ per year. Many of these trends have been consistent over a number of years, at least 10 in many cases, but as many as 30 for the results presented by Naja et al. (2003). These trends were obtained for a number of locations across the northern hemisphere, with isolated measurements also available for the southern hemisphere. There does not appear to be a significant location dependence for the trend rates, implying that these ranges would apply specifically to North America.

The rates of change may well be different in the future, but projections for future years prepared by the International Panel on Climate Change (IPCC) and reported by Vingarzan (2004) suggest that background ozone concentrations will continue to increase through 2040,2060, and 2080, but then decrease slightly to 2100 . The low end of the projected range increases from about 34 to $40 \mathrm{ppb}$, with the high end increasing from $50 \mathrm{ppb}$ in 2040 to about $85 \mathrm{ppb}$ in 2080 , then decreasing slightly to $84 \mathrm{ppb}$ in 2010 . The corresponding average projected values are about $42 \mathrm{ppb}$ in 2040, 54 ppb in 2060, 63 ppb in 2080, and 62 ppb in 2100. These projections were derived from global circulation modeling of emission scenarios developed by the IPCC (Christensen et al. 2007). 
Table 2 Reported trends in background ozone

\begin{tabular}{lcll}
\hline Rising trend (per year) & Time Period & Location & Reference and Comments \\
\hline 0.5 to $2 \%$ & Various & Various & Vingarzan (2004) \\
Little significant change & $1988-1996$ & Northern Scandinavia & Lindskog and Kindbom (2001) \\
$0.5 \pm 0.36 \mathrm{ppb}$ & $1986-2004$ & California & Jaffe et al. (2003) \\
$0.49 \pm 0.19 \mathrm{ppb}$ & $1987-2003$ & Mace Head, Ireland & Simmonds et al. (2004) \\
5 to $10 \mathrm{ppb}$ over 30 years & $1970-1999$ & Switzerland, Germany & Naja et al. (2003) \\
$1 \mathrm{ppb}$ & $1997-2000$ & Gozo, Malta & Nolle et al. (2001) \\
0.8 to $1.3 \mathrm{ppb}$ over 9 to 11 years & $1988-1998$ & Jungfraujoch, Switzerland & Bronnimann et al. (2000) \\
$0.18 \pm 0.04 \mathrm{ppb}$ & $1990-2001$ & Mace Head, Ireland & Carslaw (2005) \\
Up to $0.5 \mathrm{ppb}$ & $1973-2004$ & Remote locations & ACCENT (2006) \\
\hline
\end{tabular}

\section{Background ozone in regional-scale modeling}

Mathematical models have become indispensible tools in many areas, including the development of pollution control strategies. It is thus imperative that they include background ozone in an appropriate manner.

For regional modeling, background ozone includes the global tropospheric ozone concentrations plus the impacts of biogenic emissions within the domain. When assessing daily $8 \mathrm{~h}$ maximum ozone concentrations, background ozone can contribute significantly to the predicted values. To estimate the impacts of background ozone, CMAQ (the Community Multiscale Air Quality model) was run for the May to September 2005 period with all anthropogenic emissions set to zero.

In these runs, the southern and western boundaries in CMAQ (usually inflow) have ozone concentrations of
$35 \mathrm{ppb}$ near the surface increasing to $40,45,50,60$, and $70 \mathrm{ppb}$ in steps to the model top (100 mbars). The model itself has 15 layers in the vertical. The eastern and northern boundaries (frequently outflow) have $30 \mathrm{ppb}$ in the lowest layer. These values are based on average observed ozone profiles and were held constant with time, as sufficient information was not available to develop temporal variation of boundary conditions. Note that the model domain completely encompassed the Great Lakes, thus avoiding complications associated with locally enhanced concentrations of ozone over the lakes.

Figure 2 shows the average modelled $8 \mathrm{~h}$ maximum background ozone concentrations across the model domain. Near the boundaries, the ground level ozone concentrations are high because they have not had time to adjust to the balance between vertical mixing and dry deposition
Fig. 2 Averaged background ozone concentration (ppb) for May-September 2005 and subdomains' location

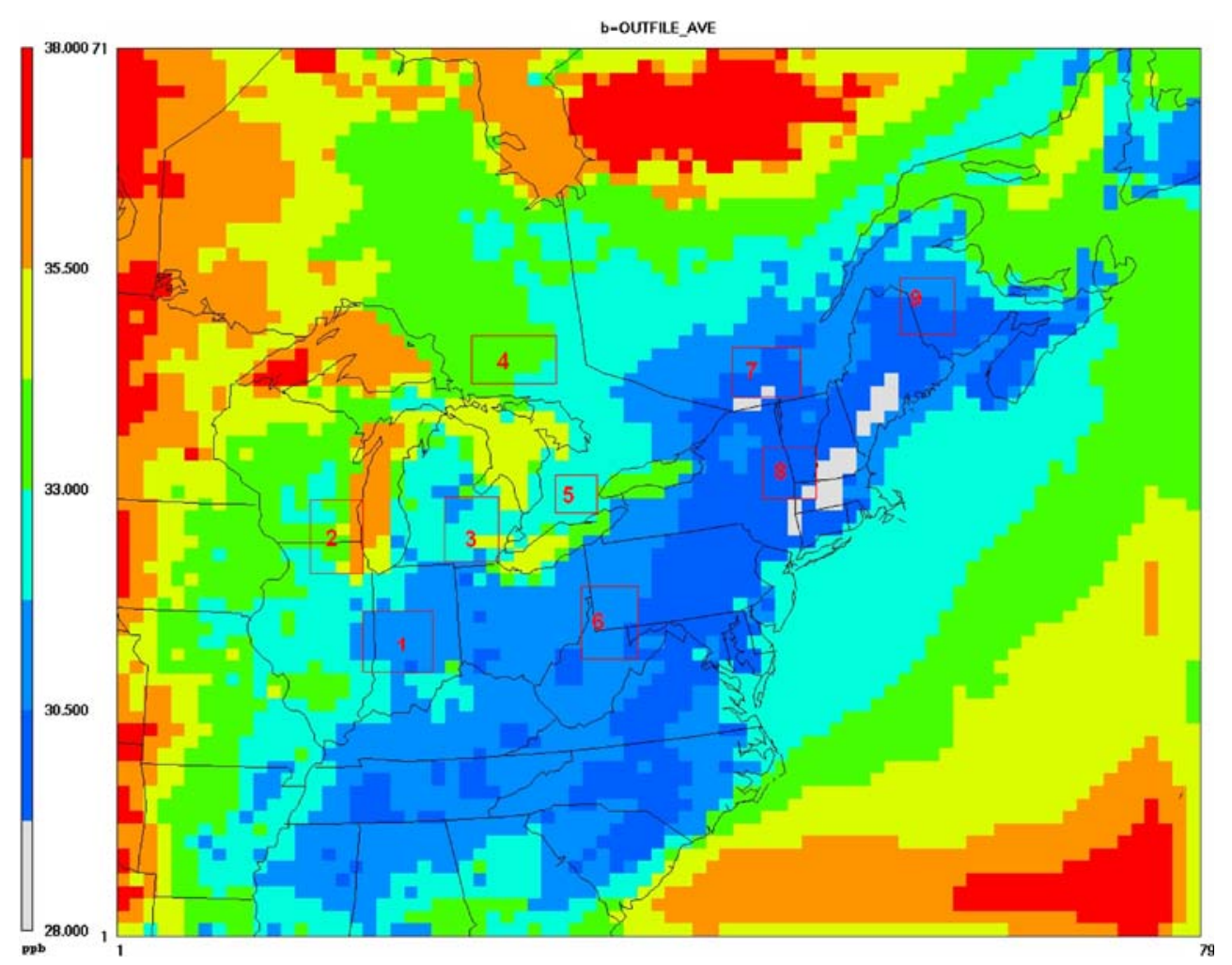


processes which affect the impacts in the inner part of the model domain. The 5 month average background $8 \mathrm{~h}$ maxima are in the 30 to $34 \mathrm{ppb}$ range in the inner portion of the model domain. Note that over large water bodies, higher background concentrations are modeled, probably because the dry deposition rates are lower over water.

Meteorology can have significant impacts on background concentrations due to the balance between mixing higher concentrations to ground level and dry deposition of ozone under different weather conditions. The distribution of the background $8 \mathrm{~h}$ maxima for subregion no. 5 (shown in Fig. 2) is illustrated in Fig. 3. It is a skewed distribution with the most frequently occurring maxima almost $3 \mathrm{ppb}$ higher than the average value. The skewed distribution suggests that, in the model, reducing concentrations at ground level by dry deposition more frequently dominates over mixing higher concentrations to ground level. Table 3 summarizes the average and the distributions of the background concentrations for nine sub-domains shown in Fig. 2. The modeled highest concentrations and the SDs were similar in all sub-domains.

An analysis of "dirty" days when the 8-h ozone concentrations, with anthropogenic emissions included, exceeded $70 \mathrm{ppb}$ showed lower contributions from background ozone by typically 1 to $3 \mathrm{ppb}$. This could be caused by more dry deposition with slow moving high pressure systems that are typical during high ozone episodes.

\section{Ozone and climate change}

Ozone in the troposphere is an important greenhouse gas. While the net impact of increasing global ozone concentrations in the troposphere on climate change is not yet properly understood, there is also a need to understand how climate change might affect ozone concentrations, as both mechanisms have potential health and ecosystem implications.

The ozone implications on climate warming are projected to be of a regional nature (i.e., its warming impact is much more closely tied to the region it originates from), as

Distribution of background ozone concentration in subdomain \#5 SW Ontario

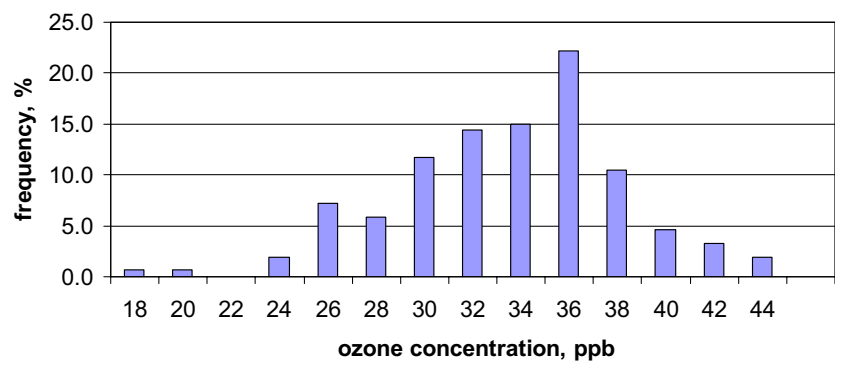

Fig. 3 Frequency distribution of background ozone concentration in South-Western Ontario for ozone season May-September 2005
Table 3 Background ozone concentration (ppb), May-September 2005

\begin{tabular}{lccccc} 
Subdomain & Average & Max & Min & SD & Averaged on "dirty" days \\
\hline 1 & 31.2 & 44.0 & 21.1 & 4.4 & 30.0 \\
2 & 34.0 & 43.9 & 23.1 & 4.2 & 32.7 \\
3 & 32.3 & 43.2 & 19.3 & 4.2 & 29.5 \\
4 & 33.1 & 46.0 & 21.9 & 4.3 & 32.4 \\
5 & 32.4 & 42.8 & 16.8 & 4.6 & 29.9 \\
6 & 30.8 & 43.3 & 16.5 & 4.4 & 28.4 \\
7 & 30.3 & 45.3 & 18.2 & 4.3 & 27.7 \\
8 & 29.6 & 44.7 & 18.7 & 4.6 & 25.1 \\
9 & 30.4 & 44.3 & 18.5 & 4.1 & 23.7 \\
\hline
\end{tabular}

ozone does not reside long enough in the lower atmosphere to spread uniformly around the globe like other greenhouse gases such as carbon dioxide. One recent modeling study by NASA Goddard Institute for Space Studies (GISS) evaluated how tropospheric ozone has changed temperatures over the past 100 years and how it has contributed to warming in specific regions of the world (Shindell et al. 2006). This study concluded that it was responsible for one third to half of the observed warming trend in the Arctic during winter and spring when ozone is transported quite efficiently from industrialized countries in the northern hemisphere to the arctic. Other researchers are currently undertaking national assessment of air quality, both ozone and aerosol, sensitivities to future climate. For example, the intramural Climate Impacts on Regional Air Quality (CIRAQ) project is developing regionally downscaled air quality predictions for North America under current and future climate conditions using the CMAQ model (Rao 2007). Some preliminary results of future climate simulations suggest extension of the ozone season across North America. Such research can provide valuable information to air quality management decisions regarding the efficacy of emission controls in the future and is an important first step towards introducing climate as a factor to consider in air quality management and the potential effects on human health/welfare.

In terms of global mean radiative forcing of the climate system, tropospheric ozone plays an important role in warming the atmosphere (Fig. 4; Forster et al. 2007). Increasing industrialization in various regions of the world in the future is thus likely to contribute to further increases in global tropospheric ozone background levels and hence to increased warmth and associated potential health implications (Murazaki and Hess 2006). Recently, it has also been suggested that ozone smog may accentuate global warming in this century by damaging plants and trees that would have helped soak up carbon emissions, thereby allowing more carbon dioxide to build up in the atmosphere (Sitch et al. 2007). Their findings suggest that the indirect effects of ozone at surface level could contribute more to 
Radiative forcing of climate between 1750 and 2005

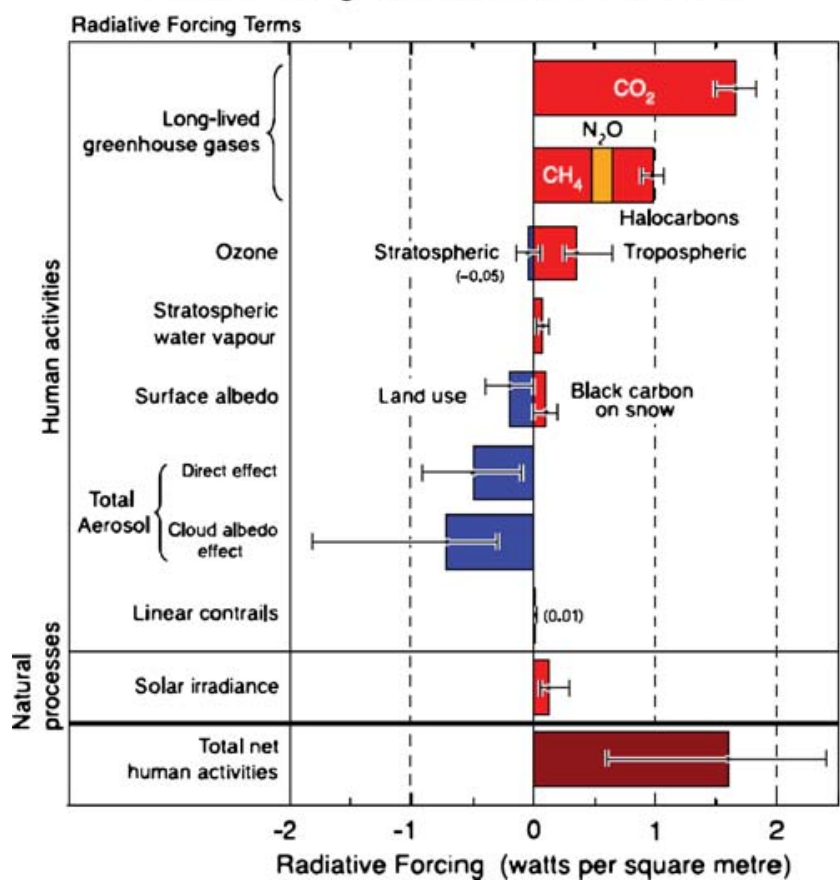

Fig. 4 Summary of the principal components of the radiative forcing of climate change. The values represent the forcings in 2005 relative to the start of the industrial era (about 1,750). From Forster et al. (2007)

global warming than the direct effects of ozone in the troposphere acting as a greenhouse gas. On the other hand, there is now an emerging body of research which suggests that warming global temperatures can increase the production of ozone vis-à-vis increased production of natural smog-forming VOCs such as isoprene emitted by trees. An added complexity to note is that global increases in isoprene can also have other implications to the complex climate system, as isoprene could be a precursor of secondary organic aerosols (SOA) which, on account of their hygroscopic nature, participate in cloud formation and result in indirect effects on climate (Noziere 2007).

Resultant increases in global and regional background ozone levels in the future could thus detrimentally affect air quality and human health through increases in total, cardiovascular, and respiratory mortality, hospital admissions for asthma, and hospital admissions for respiratory causes for older populations. As a greenhouse gas that contributes to warming of the climate system, it has a potential role in future climates of increased extreme weather events, increased number of hot days and heat stress, and the potential spread of various harmful substances and diseases such as West Nile Virus, Lyme disease, and malaria across the globe. It is thus important to consider these potential science implications of ozone in the management of air quality and climate change interactions. In the policy context, in particular, it is necessary to bear in mind the role and implications of global or hemispheric background ozone.

\section{Discussion of background ozone concentrations, trends, and implications}

A number of observations may be made concerning the background ozone concentrations and trends reported here.

- "Background" is an apparently simple concept, but different researchers have different understanding or definition of the term, sometimes making it difficult to compare results from different studies. For example, Nolle et al. (2001) reported background concentrations greater than $50 \mathrm{ppb}$, as measured on the island of Gozo, Malta. These concentrations represent the background for Malta, as care was taken to analyze only measurements made for wind trajectories which did not include Malta itself. However, Malta is located in the Mediterranean, just south of Sicily. It is close to major land-based emission sources, besides being adjacent to major shipping lanes, so that the concentrations measured here should be considered representative of the anthropogenically influenced atmosphere of the Mediterranean basin.

- The background ozone concentration in a jurisdiction or region is very important in discussing health impacts and policy options, as it cannot be controlled by measures adopted within the jurisdiction or region. In this context, it must be remembered that health impacts of ozone have been demonstrated at all concentrations, i.e., with no threshold. The background is (approximately) constant and therefore contributes continuously to the health effects. The continuous nature of the impact means that it can, in the longer term, represent a very significant portion of the overall impact.

- The assumption is often made that measurements made at high elevation are representative of the free troposphere (the portion of the troposphere above the mixing layer) and may therefore be accepted as representing background. Care must be taken in accepting this assumption, as upward mixing may occur to a greater extent than expected (Bonasoni et al. 2000) because of convective or orographic lifting, which delivers boundary layer air to such locations. In any event, in interpreting results from high elevation sites, it must be remembered that ozone concentrations tend to increase with increasing altitude.

- Substantial disagreement exists between background ozone concentrations reported by two groups working in the United States. As may be seen in Table 1, Lefohn and coworkers (Lefohn et al. 2001; Cooper et al. 2005) maintain that background ozone concentrations in North 
America and elsewhere can exceed $60 \mathrm{ppb}$, with substantial contributions to this amount coming from the stratosphere. They have reached this conclusion on the basis of a detailed analysis of measured ozone concentrations, with various methods used to segregate out the measurements which correspond to background conditions. On the other hand, the group at Harvard (Fiore et al. 2003) have applied a global atmospheric model with chemistry to derive background concentrations in the range of 25 to $35 \mathrm{ppb}$, with occasional excursions to higher values. It must be accepted that both methods are subject to some uncertainty. For example, direct analysis of measurements relies on the exclusion of contributions from regionally polluted air masses, while the modeling approach of Fiore et al. relies on the accuracy of the model and its predictions. However, it appears likely that a major part of the discrepancy is related to the question of what exactly is understood by background. The Lefohn et al. results are necessarily obtained from sites at or near the edge of the study domain, so that a clean sector or sectors can be defined. The GEOS-CHEM model predicts concentrations at all points within the study domain as an integral consequence of the simulations. In particular, Fiore et al. believe that the meteorological conditions which often lead to high ozone concentrations in eastern North America (i.e., large scale stagnation) cause the background ozone entering the domain to be substantially reduced by deposition and local scavenging. Thus, for an ozone episode in which the maximum concentration was $80 \mathrm{ppb}$ or higher, they found a background contribution of only $15 \mathrm{ppb}$ or less for the majority of episodes. The implications of this result for policy design are very important, as it means that a larger proportion of local ozone than often expected is controllable by reducing regional emissions. On the other hand, if the higher value is correct, the background concentrations are often high enough that there is essentially no hope of reducing local emissions to the point that compliance with current ozone standards or guidelines could be achieved.

- A number of reports have indicated that maximum ozone concentrations have reduced over the last several years, responding to reductions in the emissions of the precursors, $\mathrm{NO}_{x}$ and VOC. However, concentrations at the lower end of the frequency distribution have tended to increase. This is interpreted as being reflective partly of a worldwide increase in background concentrations, but is also believed to be a consequence of reduced $\mathrm{NO}_{x}$ emissions, resulting in reduced chemical scavenging of ozone concentrations (Wallasch 2003; Chevalier et al. 2007).

- It was noted in much of the literature surveyed that concentrations of ozone produced anthropogenically in the local region tend to peak in the summer, whereas natural background concentrations tend to peak in the spring. The latter observation is believed to be a consequence of a pulse of natural emissions released at the start of the growing season, but may also include a contribution from stratospheric input. It is interesting that Carslaw (2005) has shown that the seasonal profile measured at Mace Head, on the western coast of Ireland, has changed in recent years from one having a summer maximum to a spring maximum, suggesting that emission reductions in Europe have decreased anthropogenic production to the point that the major component of ozone measured at the site is background.

- There is wide agreement that ozone can be transported from one continent to another. Thus up to 5 or $10 \mathrm{ppb}$ of ozone produced from North American precursor emissions can reach Europe, with a similar amount from Asia reaching western North America (Fiore et al. 2002; Vingarzan 2004; McKendry 2006; Liang et al. 2007). This is of great importance, given the rapid industrialization of China and India, which will almost inevitably lead to increases in emissions from the region. It is clear that international agreement(s), beyond what is under discussion between Canada and the US, will be required for success in the control of ozone.

- The literature reviewed has provided information on long-term trends of background ozone and also on the seasonal cycles of concentration. However, no information was found on shorter-term variations in background concentration. For example, Lefohn et al. maintain that significant contributions arise from intrusions of stratospheric air, but it is not clear how long the background concentration will remain elevated after such an event. It is also not clear what sort of diurnal pattern will be followed by background ozone. It is known that there is often very little by way of a diurnal cycle at remote locations, but it is important also to know how the background concentration varies through the day at locations which are also influenced by locally and regionally produced ozone. This knowledge would be required, for example, when separating the health costs of ozone due to local and regional emissions from those purely due to background.

- With a few exceptions noted above, the current literature indicates that background ozone concentrations are increasing and will continue to do so until the end of the 21 st century. It is very difficult to determine how much of the increase is in the anthropogenic component and how much is purely natural. The modeling work of Fiore et al. (2003) suggests that the natural component is generally in the 10 to $25 \mathrm{ppb}$ range and never exceeds $40 \mathrm{ppb}$. Compare this range with the concentrations measured at Pic du Midi in the mid-nineteenth century (Fig. 1), which were approxi- 
mately 10 to $15 \mathrm{ppb}$. If it is assumed that these concentrations are accurate and that they contain no anthropogenic contribution, it may be inferred that there has been a small increase in the natural component of the background. Simmonds et al. (2004) suggest that some of the increase in background ozone concentrations may be associated with increasing burning of biomass in the tropical and boreal regions. However, at least some of this burning should be considered to be anthropogenic.

- There is a two-way link between troposphere ozone and climate change, as discussed in the "Ozone and climate change" section. Ozone in the troposphere is a greenhouse gas, and ozone concentrations are influenced by climate changes.

\section{Conclusions}

It is now widely recognised that background ozone may form a significant part of the concentration experienced at many locations. This can be extremely important, as the background concentration is the level below which concentrations cannot be reduced by local efforts alone. The background has both a natural and an anthropogenic component and is a hemispheric phenomenon. Reported background ozone concentrations are similar for North America and Europe. The limited number of values reported for the southern hemisphere tend to be somewhat lower than for the northern hemisphere.

In discussing background ozone, it is important to be clear about what is meant by the term. In particular, distinction must be made between the concentration of ozone entering a region of concern as a result of emissions occurring outside the area, and the concentration at any point within the region of concern resulting from the combined effect of natural sources anywhere and anthropogenic sources outside the region.

There is a clear need to refine estimates of background ozone, in particular, resolving the discrepancies typified by the opposing views expressed in the work of Lefohn et al. (2001), Cooper et al. (2005), and Fiore et al. (2003). This includes the need for clarity on the role of the stratosphere as a source for troposphere ozone. The difference is important because the background concentration is not controllable within a jurisdiction. Thus, a low background concentration suggests that a large proportion of the total ozone concentration can be controlled, given the introduction of appropriate measures. For example, if the background is $25 \mathrm{ppb}$, local, anthropogenically produced ozone must be reduced to $40 \mathrm{ppb}$ to achieve a standard of $65 \mathrm{ppb}$. However, if the background concentration is high, say $55 \mathrm{ppb}$, the local anthropogenic component will have to be reduced to $10 \mathrm{ppb}$, which is much more difficult.
Ozone lifted to levels above the boundary layer can be transported very long (intercontinental) distances. As a result, Asia, North America, and Europe can all contribute to each other's background ozone concentrations. This means that, although agreement with one's immediate neighbors on emission reductions is very important in addressing the ozone problem, international agreements at much longer range must also be considered. In particular, the rapid industrial growth in Asia and the accompanying increased precursor emissions, will need to be monitored and addressed.

The temporal patterns of background ozone need improved definition, on scales from diurnal upwards. In addition, an assessment is required of the relevance of temporal variability in background ozone in the calculation of health and other costs associated with ozone, specifically in relation to the separation of controllable and noncontrollable impacts.

Related to the assessment of costs of ozone damage, there is a continuing urgent need for improved data on health and other costs. Current estimates are in some areas based on very limited data.

\section{References}

ACCENT (2006) First ACCENT Symposium, Urbino, Italy, Sept. 2005, Ed. F. Raes and J. Hjorth. Question answers may be found at http://www.accent-network.org/index.cfm?objectid=6023C479BCDC-BAD1-A0D3EB5D0C950580

Altshuller AP, Lefohn AS (1996) Background ozone in the planetary boundary layer over the United States. JAWMA 46:134-141

Auvray M, Bey I (2005) Long-range transport to Europe: Seasonal variations and implications for the European ozone budget. J Geophys Res 110, D11303, DOI 10.1029/2004JD005503

Bonasoni P, Stohl A, Cristofanelli P, Calzolari F, Colombo T, Evangelisti F (2000) Background ozone variations at Mt. Cimone Station. Atmos Environ 34:5183-5189

Bronnimann S, Schuepbach E, Zanis P, Buchmann B, Wanner H (2000) A climatology of regional background ozone at different elevations in Switzerland (1992-1998). Atm Env 34:5191-5198

Carslaw DC (2005) On the changing seasonal cycles and trends of ozone at Mace Head, Ireland. Atmos Chem Phys 5:3441-3450

Chevalier A, Gheusi F, Delmas R, Ordonez C, Sarrat C, Zbinden R, Thouret V, Athier G, Cousin J-M (2007) Influence of altitude on ozone levels and variability in the lower troposphere: a groundbased study for western Europe over the period 2001-2004. Atmos Chem Phys Discuss 7:1327-1356

Christensen JH, Hewitson B, Busuioc A, Chen A, Gao X, Held I, Jones R, Kolli RK, Kwon W-, Laprise R, Magaña Rueda V, Mearns L, Menéndez CG, Räisänen J, Rinke A, Sarr A, Whetton P (2007) Regional climate projections. In: Solomon S, Qin D, Manning M, Chen Z, Marquis M, Averyt KB, Tignor M, Miller HL (eds) Climate change 2007: The physical science basis. Contribution of working group I to the fourth assessment report of the intergovernmental panel on climate change. Cambridge University Press, Cambridge, United Kingdom and New York, NY, USA

Cooper O, Stohl A, Hübler G, Parrish DD, Tuck A, Kiladis G, Oltmans SJ, Johnson BJ, Shapiro M, Lefohn A (2005) Direct transport of polar stratospheric ozone into the lower troposphere and marine 
boundary layer of the tropical Pacific Ocean. J Geophys Res 110, D23310, DOI 10.1029/2005JD005783

Finlayson-Pitts B, Pitts J Jr. (1999) Chemistry of the upper and lower atmosphere. Elsevier.

Fiore AM, Jacob DJ, Bey I, Yantosca RM, Field BD, Fusco AC, Wilkinson JG (2002) Background ozone over the United States in summer: origin, trend, and contribution to pollution episodes. J Geophys Res 107(D15):4275

Fiore A, Jacob DJ, Liu H, Yantosca RM, Fairlie TD, Li Q (2003) Variability in surface ozone background over the United States: Implications for air quality policy. J Geophys Res 108(D24):4787

Forster P, Ramaswamy V, Artaxo P, Berntsen T, Betts R, Fahey DW, Haywood J, Lean J, Lowe DC, Myhre G, Nganga J, Prinn R, Raga G, Schultz M, Van Dorland R (2007) Changes in atmospheric constituents and in radiative forcing. In: Solomon S, Qin D, Manning M, Chen Z, Marquis M, Averyt KB, Tignor M, Miller HL (eds) Climate change 2007: The physical science basis. Contribution of working group I to the fourth assessment report of the intergovernmental panel on climate change. Cambridge University Press, Cambridge, UK, and New York, USA

Gros V (2006) in Background ozone and long distance transport of nitrogen oxides. Global change magazine for schools. Published by ACCENT, http://www.atmosphere.mpg.de/enid/Nr2JuneO5 Research_5og.html

Hocking WK, Carey-Smith T, Tarasick DW, Argall PS, Strong K, Rochon Y, Zawadzki I, Taylor PA (2007) Detection of stratospheric ozone intrusions by wind profiler radars. Nature 450:281

IPCC (2001) Intergovernmental panel on climate change: Third assessment report. Cambridge University Press.

Jaffe DA, Parrish D, Goldstein A, Price H, Harris J (2003) Increasing background ozone during spring on the west coast of North America. Geophys Res Letts 30(12):1613

Lefohn AS (2001) Present-day variability of background ozone in the lower troposphere, http://www.asl-associates.com/background1/index.htm

Lefohn AS, Oltmans S, Dann T, Singh H (2001) Present day variability of background ozone in the lower troposphere. J Geophys Res 106:9945-9958

Liang Q, Jaeglé L, Hudman RC, Turquety S, Jacob DJ, Avery MA, Browell EV, Sachse GW, Blake DR, Brune W, Ren X, Cohen RC, Dibb JE, Fried A, Fuelberg H, Porter M, Heikes BG, Huey G, Singh HB, Wennberg PO (2007) Summertime influence of Asian pollution in the free troposphere over North America. J Geophys Res 112, D12S11, DOI 10.1029/2006JD007919

Lin C-YC, Jacob DJ, Munger JW, Fiore AM (2000) In creasing background ozone in surface air over the United States. Geophys Res Lett 27:3465-3468

Lindskog A, Kindbom K (2001) Ozone in remote areas: Seasonal cycles, EUROTRAC-2 Symposium 2000 Proceedings. In: Midgley PM, Reuther M, Williams M (ed) Springer-Verlag, Berlin

Marenco A, Gouget H, Nedelec P, Pages J-P (1994) Evidence of a long-term increase in troposphere ozone from the Pic du Midi data series. J Geophys Res 99(D8):16617-16632

McKendry IG (2006) Background concentrations of $\mathrm{PM}_{2.5}$ and ozone in British Columbia. Report to the BC Ministry of the Environment, http://www.env.gov.bc.ca/air/airquality/pdfs/ background_pm25_ozone.pdf
Munger JW, Doddridge B, Clark R (2002) Interpretation of $\mathrm{NO}_{y}, \mathrm{O}_{3}$ and CO data from the Northeast Oxidant and Particle Study, http://ams.confex.com/ams/pdfpapers/29960.pdf

Murazaki K, Hess P (2006) How does climate change contribute to surface ozone change over the United States? J Geophys Res 111, DOI 10.1029/2005JD005873

Naja M, Akimoto H, Staehelin J (2003) Ozone in background and photochemically aged air over central Europe: Analysis of longterm ozonesonde data from Hohenpeissenberg and Payerne. J Geophys Res 108(D2):4063

Nolle M, Ellul R, Gusten H, Heinrich G (2001) Long-term background ozone and carbon monoxide measurements on the Maltese Islands, Proceedings of 8th European Symposium on the Physico Chemical behaviour of Atmospheric Pollutants. September 2001, Turin, Italy

Noziere B (2007) Secondary organic aerosols: Thinking outside the smog chamber. Global Change Newsletter, No. 69, May 2007, 4-8

OAQPS (2007) Ozone National Ambient Air Quality Standards (NAAQS) Staff Paper and Draft Health/Environmental Assessments. US EPA 2007. http://www.epa.gov/ttn/naaqs/standards/ ozone/data/2007_01_ozone_staff_paper.pdf

Oltmans SJ, Lefohn AS, Harris JM, Galbally I, Scheel HE, Bodeker G, Brunke E, Claude H, Tarasick D, Johnson BJ, Simmonds P, Shadwick D, Anlauf K, Hayden K, Schmidlin F, Fujimoto T, Akagi K, Meyer C, Nichol S, Davies J, Redondas A, Cuevas E (2006) Long-term changes in tropospheric ozone. Atmos Environ 40:3156-3173

Pochanart P, Kato S, Katsuno T, Akimoto H (2004) Eurasian continental background and regionally polluted levels of ozone and CO observed in northeast Asia. Atmos Environ 38:1325-1336

Rao ST (2007) Climate Impacts on Regional Air Quality (CIRAQ): Modeling Ozone (and PM2.5) sensitivities to future climate. Presentation to Ontario ministry of the environment, June 2007.

Scheel HE, Areskoug H, Geiss H, Gomiscek B, Granby K, Haszpra L, Klasinc L, Kley D, Laurila T, Lindskog A, Roemer M, Schmitt R, Simmonds P, Solberg S, Toupance, G (1997) On the spatial distribution and seasonal variation of lower-troposphere ozone over Europe. J Atmos Chem 28:11-28

Seinfeld JH, Pandis SN (1998) Atmospheric chemistry and physics: from air pollution to climate change. A Wiley-Interscience publication, USA

Shindell D, Faluvegi G, Lacis A, Hansen J, Ruedy R, Aguilar E (2006) Role of tropospheric ozone increases in 20th-century climate change. J Geophys Res 111:D08302, DOI 10.1029/2005JD006348

Simmonds PG, Derwent RG, Manning AL, Spain G (2004) Significant growth in surface ozone at Mace Head, Ireland, 1987-2003. Atm Env 38:4769-4778

Sitch S, Cox PM, Collins WJ, Huntingford C (2007) Indirect radiative forcing of climate change through ozone effects on the landcarbon sink. Nature 448:791-794 (advanced online publication)

Vingarzan R (2004) A review of surface ozone background levels and trends. Atm Env 38:3431-3442

Wallasch M (2003) EMEP Assessment Report, Part II, National Contributions. In: Bartnicki J, Lovblad G (ed) Available at http:// www.emep.int 